\title{
Multiple spinal extradural cysts causing progressive paraparesia: case report and review of literature
}

\author{
Elton Gomes da Silva1, Vinícius Teixeira Ribeiro', \\ Bruno Vieira Scarpim ${ }^{1}$, Yvens Barbosa Fernandes ${ }^{1}$ \\ Division of Neurosurgery, Department of Neurology, School of Medical Sciences, State University of Campinas (FCM/ \\ Unicamp).
}

\begin{abstract}
Multiple meningeal extradural cysts are extremely rare. The clinical presentation varies from asymptomatic patients to important symptoms due to spinal cord compression. This article reports the case of a girl with multiple meningeal extradural cysts with progressive paraparesis and hypoesthesia on inferior limbs. The MRI showed multiple extradural cysts between C7 and L1. A partial resection was made at the cystis, reflecting a improve at the postoperative follow up of the patient. The management of asymptomatic cases is usually followed up clinical and radiologically. At the management of the symptomatic cases, the resection of the cysts is the most indicated treatment, even for patients with a long-standing history of compression. However the partial removal has as good results as the total one. The authors review the literature and show a subtotal resection of the cysts did not change the evolution of the presentation.
\end{abstract}

\section{KEYWORDS}

Bone cysts, spine, arachnoid cysts, spinal cord diseases, meninges/abnormalities, meninges/surgery.

\section{RESUMO}

Cistos espinhais extradurais múltiplos causando paraparesia progressiva: relato de caso e revisão da literatura

Cistos espinhais extradurais meníngeos múltiplos são extremamente raros. A apresentação clínica varia de pacientes assintomáticos a sintomas importantes devidos à compressão da medula espinhal. Este artigo relata o caso de uma garota com cistos extradurais meníngeos múltiplos com paraparesia progressiva e hipoestesia de membros inferiores. A ressonância magnética mostrou cistos extradurais múltiplos entres C7 e L1. Uma ressecção parcial foi realizada nos cistos, levando à melhora no seguimento pós-operatório da paciente. O tratamento de casos assintomáticos, geralmente, se resume a seguimento clínico e radiológico. Em casos sintomáticos, a ressecção dos cistos é o tratamento mais indicado, mesmo para pacientes com longa história de compressão. Entretanto, a remoção parcial costuma ter bons resultados, semelhante à ressecção total. Os autores revisam a literatura e detalham que uma ressecção parcial dos cistos não mudou o prognóstico da paciente.

\section{PALAVRAS-CHAVE}

Cistos ósseos, coluna vertebral, cistos aracnóideos, doenças da medula espinal, meninges/ anormalidades, meninges/cirurgia.

\section{Introduction}

Spinal epidural meningeal cysts (or arachnoid extradural cysts), result from herniations of the arachnoid through congenitally or acquired dural defects. ${ }^{1,2}$ The most common location is the thoracic spine, followed in frequency by the lumbar and rarely on the cervical spine. ${ }^{3-5}$ Multiple spinal extradural meningeal cysts are rare, only five cases were reported up to this moment..$^{6-10}$ The clinical presentation varies from asymptomatic patients up to important spinal cord compression manifesting as paraparesia-paraplegia and sensory symptoms, depending on the location, size and progression of the cysts..$^{2-6,10-13}$ Surgical intervention is indicated on symptomatic cases, avoiding operating on asymptomatic lesions because this might generate spinal instability and iatrogenic deficits. ${ }^{6-8,12,14}$

1. Neurosurgeon, Department of Neurology, State University of Campinas (Unicamp), Campinas, SP, Brazil. 
This article presents the case of a patient with multiple spinal extradural meningeal cysts on the cervical and thoracic spine, spinal cord compression, beyond the treatment given.

\section{Case report}

A fifteen years-old female was evaluated with progressive weakness in inferior limbs that started three years ago, ending up a need of aid in locomotion. She had no sphincterian complains nor even history of spinal trauma. Physical examination showed that she had in superior limbs muscle strength $5 / 5$ and degree $3 / 5$ in inferior limbs in proximal muscles and 2/5 distally, a sensitive level on T9 with diminished tactile and pain sensation, worst on the right side. She also had hyperreflexia in inferior limbs with positive clonus and Babinsky signs bilaterally. MRI (magnetic resonance imaging) of spine showed cystic lesions with thin walls and septations posteriorly compressing the spinal cord from C7 through L1, with the highest degree of compression from T6 through T10 (Figure 1).

Surgical approach of the lesions was performed by laminectomy from T6 through T8. After laminectomy and exposition of the extradural space three cysts were removed, one of them having a clear dural communication. This communication was the probable herniation site and was closed by suture after the removal. The pathological examination of the material revealed extradural meningeal cysts (Figure 2). After the surgical

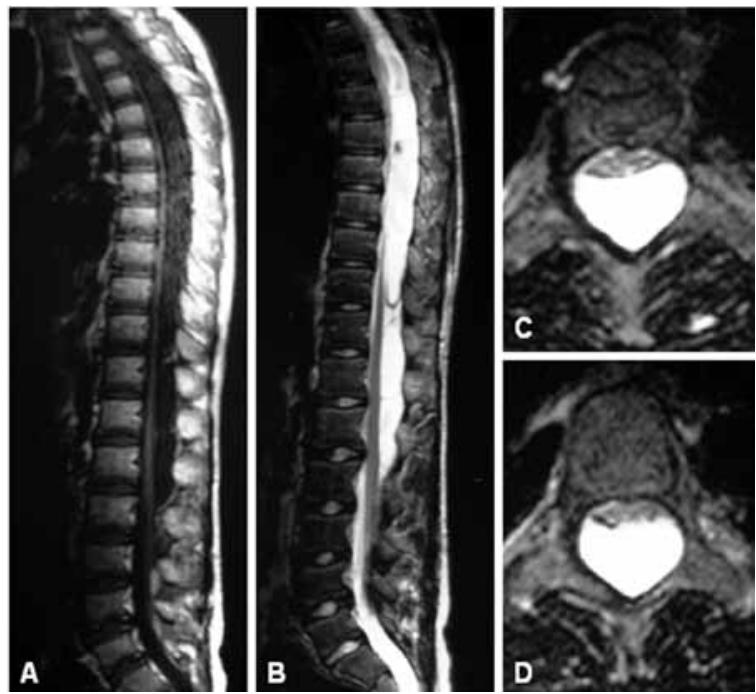

Figure 1 - (A and B) MRI with sagital plane on T1 and T2, showing multiple cystic posteriorly located lesions compressing the spinal cord anteriorlly; (C and D) axial images on T2 showing the points where the compression was most evident. MRI: magnetic resonance imaging. procedure the patient had a significant neurological improvement, being able to walk without assistance, beyond a great improvement on the sensory symptoms.

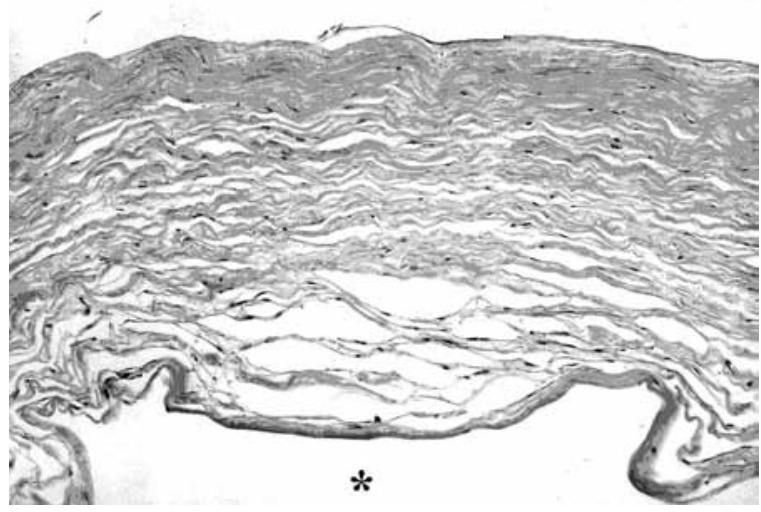

Figure 2 - Histological image of the cyst showing the loose connective tissue, which represented the dura mater. It was not possible to observe the arachnoid laminae, it is usually very thin and inconstant at the inner part of the cyst (asterisk). Hematoxilin \& eosin, original magnification X 100.

\section{Discussion}

Spinal extradural meningeal cysts are rare, representing only $3 \%$ of all primary space-occupying lesions, there is a lot of controversies regarding its pathogenesis. It is also known that there is no race or age predilection for these lesions. ${ }^{2,15}$ Pathological presentation is characterized by the presence of a thin internal layer of arachnoid, sometimes inconstant, surrounded by an external layer of collagen fibers that corresponds to the dura mater. ${ }^{1}$ The mechanism of formation of these cysts is not defined, and some authors believe that congenital or acquired points of weakness through the dura mater permit arachnoid herniation with posterior formation of these lesions..$^{2-4}$ The most common location is the lower thoracic spine although they might be found anywhere on the dural sac. ${ }^{3,5}$

The clinical symptoms are caused by spinal cord compression and usually are manifested as progressive tetra or paraparesia, flaccid or spastic associated to sensory and sphincterian symptoms. The exam of choice for evaluation is MRI, it is capable of delineating the lesions as well as the relation with the spinal cord and differential diagnosis, although some authors recommend myelography, that can show a connection between the cyst and the subarachnoid space. The diagnosis is only established after radiological, surgical and pathological confirmation. ${ }^{16-19}$

The five cases of multiple cysts at the literature present patients with ages between nine and 32 years-old, shown on table 1, with an improvement on all of them after resection of the lesions. ${ }^{6-10}$ 


\begin{tabular}{|c|c|c|c|c|}
\hline Author and year & Age (years), sex & Level of lesions & Signs and symptoms & Treatment \\
\hline Kronborg, $1967^{9}$ & $13, \mathrm{~F}$ & T4-T12 & Spastic paraplegia & Removal and suture of the dural defects \\
\hline Masana et al., $1986^{12}$ & $33, \mathrm{M}$ & $\mathrm{T} 5-\mathrm{T} 10$ & Spastic paraplegia & Removal and closure of the dural defect \\
\hline Myles et al., $1997^{13}$ & $9, \mathrm{~F}$ & $\mathrm{~T} 2-\mathrm{S} 1$ & $\begin{array}{l}\text { Spastic paraplegia with sensory } \\
\text { level in T5-6 and below and } \\
\text { sphincterian symptoms }\end{array}$ & $\begin{array}{l}\text { Total excision and cauda } \\
\text { equina level untreated }\end{array}$ \\
\hline Takagaki et al., $2006^{18}$ & $11, \mathrm{M}$ & T5-L5 & $\begin{array}{l}\text { Paraparesia and hyperesthesia T8-10 } \\
\text { and hypesthesia in T10 and below }\end{array}$ & $\begin{array}{l}\text { Total excision and cauda } \\
\text { equina level untreated }\end{array}$ \\
\hline Marbacher et al., $2007^{10}$ & $31, \mathrm{~F}$ & T7-L3 & $\begin{array}{l}\text { Paraplegia and hypesthesia } \\
\text { in } \mathrm{L} 4 \text { and below }\end{array}$ & $\begin{array}{l}\text { Subtotal excision and } \\
\text { thoracic level untreated }\end{array}$ \\
\hline Present case & $15, \mathrm{~F}$ & C7-L1 & $\begin{array}{l}\text { Paraparesis with hypoesthesia } \\
\text { in T9 and below }\end{array}$ & $\begin{array}{l}\text { Subtotal excision and } \\
\text { suture of dural defect }\end{array}$ \\
\hline
\end{tabular}

Based on the above discussion, there is not much controversy on the treatment of symptomatic cases; it is indicated resection of the cysts with suture of the dural defects to avoid reformation of the cysts, even in patients with a prolonged history of compression. ${ }^{2,6-8,15,20}$ But the partial resection has the advantage comparing to the total resection for causing less risks to the patient. In the present case, we removed three cysts on the mid thoracic level and the patient had an improvement on her deficits after the surgery. The remaining cysts were not approached and the patient is being followed on our clinic with a progressive improvement of her clinical symptoms.

\section{Conclusion}

The treatment of multiple spinal meningeal cysts is indicated in patients with symptoms of spinal cord compression. Partial resection showed good results in two cases presented at the literature. The partial resection has less comorbity than total removal in this lesion. Larger series and longer follow up will be necessary to have a better understanding of these lesions.

\section{Acknowledgments}

We thank at teachers Dr. Luciano de Sousa Queiroz (Department of Pathologic Anatomy of Unicamp), and Dra. Verônica de Araújo Zanardi (Department of Radiology of Unicamp), and Rachel Jurca Accioly for the support.

\section{References}

1. Burger PC, Scheithauer BW, Vogel FS. Surgical pathology of the nervous system and its coverings. Philadelphia: Churchill Livingstone; 2002.

2. Wilkins RH. Intraspinal cysts. In: Wilkins RH, Rengachary SS, editors. Neurosurgery. New York: McGraw-Hill; 1996. p. 3509-19.

3. Cloward RB. Congenital spinal extradural cysts: case report with review of literature. Ann Surg. 1968;168(5):851-64.

4. Gortvai P. Extradural cysts of the spinal canal. J Neurol Neurosurg Psychiatry. 1963;26:223-30.

5. Martin G. Spinal cord herniation into an extradural arachnoid cyst. J Clin Neurosci. 2000;7(4):330-1.

6. Kronborg O. Extradural spinal cysts. A literature survey and a case of multiple extradural cysts. Dan Med Bull. 1967;14(1):46-8.

7. Marbacher S, Barth A, Arnold M, Seiler RW. Multiple spinal extradural meningeal cysts presenting as acute paraplegia. Case report and review of the literature. J Neurosurg Spine. 2007;6(5):465-72.

8. Masana Y, Yamada K, Ozaki K, Ushio Y, Hayakawa T, Mogami $\mathrm{H}$, et al. Spinal multiple extradural cyst. Case report. Neurol Med Chir (Tokyo). 1986;26(5):405-8.

9. Myles LM, Gupta N, Armstrong D, Rutka JT. Multiple extradural arachnoid cysts as a cause of spinal cord compression in a child. Case report. J Neurosurg. 1999;91(1 Suppl):116-20.

10. Takagaki T, Nomura T, Toh E, Watanabe M, Mochida J. Multiple extradural arachnoid cysts at the spinal cord and cauda equina levels in the young. Spinal Cord. 2006;44(1):59-62.

11. Joaquim $A F$, da Silva EG, dos Santos MJ, Honorato DC. Giant cervico-thoracic extradural arachnoid cyst. Arq Neuropsiquiatr. 2009;67(1):117-8.

12. Prevedello DM, Tatsui CE, Koerbel A, Grande CV, Cordeiro JG, Araújo JC. Ventral extradural spinal meningeal cyst causing cord compression: neurosurgical treatment. Arq Neuropsiquiatr. 2005;63(3B):855-8.

13. Sato K, Nagata K, Sugita $Y$. Spinal extradural meningeal cyst: correct radiological and histopathological diagnosis. Neurosurg Focus. 2002;13(4):ecp1. 
14. Freidberg SR, Fellows T, Thomas CB, Mancall AC. Experience with symptomatic spinal epidural cysts. Neurosurgery. 1994;34(6):989-93.

15. Tarlov EC, Geyer CA. Intraspinal cerebrospinal fluid cysts. In: Schmidek HH, Roberts DW, editors. Sckmidek and Sweet's operative neurosurgical techniques: indications, methods and results. Philadelphia: Elsevier; 2006. p. 477-83.

16. Boisserie-Lacroix M, Bouin H, Joullie M, Laurent F, Biset JM, Drouillard J, et al. The value of MRI in the study of spinal extradural arachnoid cysts. Comput Med Imaging Graph. 1990;14(3):221-3.

17. Chen CJ, Ro LS. The MRI signs of spinal arachnoid diverticula. Neuroradiology. 1997;39(6):446-9.

18. Kendall BE, Valentine AR, Keis B. Spinal arachnoid cysts: clinical and radiological correlation with prognosis. Neuroradiology. 1982;22(5):225-34.
19. Miyamoto M, Kim K, Matsumoto R, Isobe M, Isu T. Utility of preoperative magnetic resonance imaging myelography for identifying dural defects in patients with spinal extradural arachnoid cysts: case report. Neurosurgery. 2006;59(4):E941.

20. Raimondi AJ, Gutierrez FA, Di Rocco C. Laminotomy and total reconstruction of the posterior spinal arch for spinal canal surgery in childhood. J Neurosurg. 1976;45(5):555-60.

\section{Correspondence address}

Elton Gomes da Silva

Departamento de Neurologia - FCM/Unicamp

Rua Tessália Vieira de Camargo, 126, Barão Geraldo

13083-970 - Campinas, SP, Brazil

Telephone: (19) 3521-7372

E-mail: elgosi@yahoo.com.br 